\title{
STUDY ON IMPEDIMENTS AND SUCCESS OF BUILDING BYELAWS IMPLEMENTATION IN LAHORE, PAKISTAN
}

\author{
Dr. Muhammad Asim* \\ Dr. Saima Gulzar** \\ Muhammad Mashood Ali*** \\ Rumana Khan Shirwani****
}

\begin{abstract}
Building regulations are a silent protector to the general public. These are mostly not well recognized unless a situation arises where regulations are felt inadequate or not enforced. In Lahore a number of authorities are present for the same purpose. This research aims at studying the building regulations of the city's four different authorities i.e. Lahore Development Authority (LDA), Town Municipal Administration (TMA), Lahore Cantonment Board (LCB) and Model Town Cooperative Society (MCS), and assesses the underlying causes for their implementation failures and successes. Along with reviewing the international practices, the study identifies respondents from the general public and building officials and thus tabulates the obtained results for analyzing the efficiency of a building authority. Socioeconomic surveys as well as interview surveys have been conducted, in the light of which the working of all four authorities in relevance to different attributes have been assessed. The results reveal that the MCS has the most efficient building regulations mechanism and portrays an overall satisfactory condition. Recommendations have been made to identify tools for better implementation of building byelaws as well as provide an insight to the user for legalized building construction.
\end{abstract}

Keywords: Building Byelaws, Implementation, Building Control Authorities, Lahore

\section{INTRODUCTION}

Building control is a core element of city planning which shapes the overall development. These are a set of rules through which one can discern the bottom standard requirements for construction of buildings. It is also referred as building code in many countries. Such laws refer to the certain standards and specifications designed for health and comfort of the building users and to provide safety to the public. The basic purpose of building byelaws is to allow disciplined and systematic growth of buildings and towns and to ensure proper utilization of space.

Lahore is a unique city as it has multiple authorities exercising building control as compared to other cities of Pakistan. There are Cantonment Boards (purely military controlled area), LDA which is a civilian institution and local government unit called TMA. Besides there are cooperative authorities, for instance the MCS, which exercises building control. All responsible authorities have different mechanisms of implementing the building byelaws.

Different authorities have their own byelaws according to their areas of jurisdiction, for instance LDA has its own building regulations for newly developed schemes. Similarly TMA have their control on build up areas of Lahore, so they have their own regulations which best suit them. Furthermore, Cantonment Board is a military organization which has its own building byelaws and rules for the concerned areas.

The main focus of the study is to analyse the role of the four cited authorities and what are the factors and underlying

\footnotetext{
* Dr. Muhammad Asim, Assistant Professor, City and regional Planning Department, University of Engineering and Technology, Lahore. Email correspondance: asim_planner@yahoo.com

** Dr. Saima Gulzar, Associate Professor, School of Architecture and Planning, University of Management of Technology, Lahore. Email correspondance: saima.gulzar@umt.edu.pk

$* * *$ Muhammad Mashood Arif, M. Sc Research Scholar, Hasslet University, Belgium.

$* * * *$ Rumana Khan Shirwani, Assistant Professor, School of Architecture and Planning, University of Management of Technology, Lahore. Email correspondance: rumana.shirwani@umt.edu.pk
} 
causes due to which building byelaws are successfully being implemented and any impediments that these authorities face.

Figure 1shows the location of these four authorities in the city.

\section{RESEARCH METHODOLOGY}

Building byelaws mainly include standards for setbacks, building heights, mandatory spaces and in more advance level building direction, parking spaces, emergency and fire exits, building texture and façade elevations. LDA is mostly regulating the new development in Lahore and TMA has control over build-up settlements, while areas under Cantonment are monitored by Cantonment Boards. On the other hand Cooperative Societys have their building byelaws which are implemented on areas like Modal Town. For assessing the building byelaws, as described by these authorities, few areas have been selected which fall under their respective jurisdictions.

The following areas are taken under the above mentioned regulating authorities (see Table 1)
Furthermore, Figure 2 gives an overview of the areas chosen and the location of the areas where surveys have been carried out.

Literature review was done for identifying the best and failing urban practices in different parts of the world with respect to implementation of building byelaws. To have a deeper insight into the subject, opinion from the general public and authority officials have been sought with the help of structured questionnaire forms. Socio-economic survey has also been conducted by stratified sampling (Anon, 2015) on the basis of central limiting theorem

Table-1: Authority VS Respective surveyed areas

\begin{tabular}{|l|l|}
\hline \multicolumn{1}{|c|}{ Authority } & Area under the authority \\
\hline TMA Ravi Town & $\begin{array}{l}\text { Badami Bagh, Shadbagh, } \\
\text { Misri Shah }\end{array}$ \\
\hline $\begin{array}{l}\text { Lahore Development } \\
\text { Authority }\end{array}$ & Township Lahore \\
\hline $\begin{array}{l}\text { The Cooperative Modal } \\
\text { Society }\end{array}$ & Modal Town, Lahoe \\
\hline $\begin{array}{l}\text { Lahore Cantonment } \\
\text { Board }\end{array}$ & Sadar, PF Colony. Ali Park \\
\hline
\end{tabular}

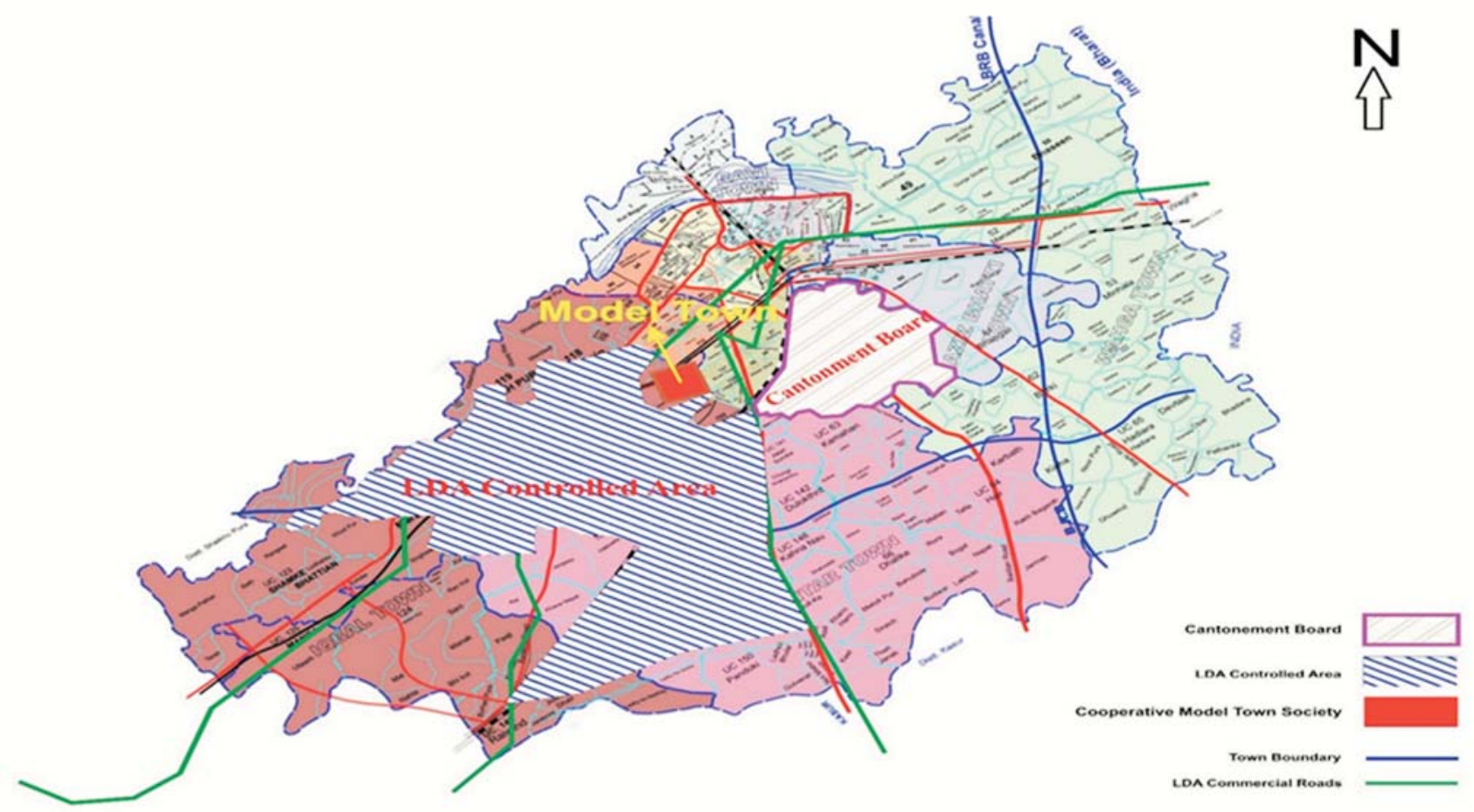

Figure-1: Building Control Authorities in Lahore. 


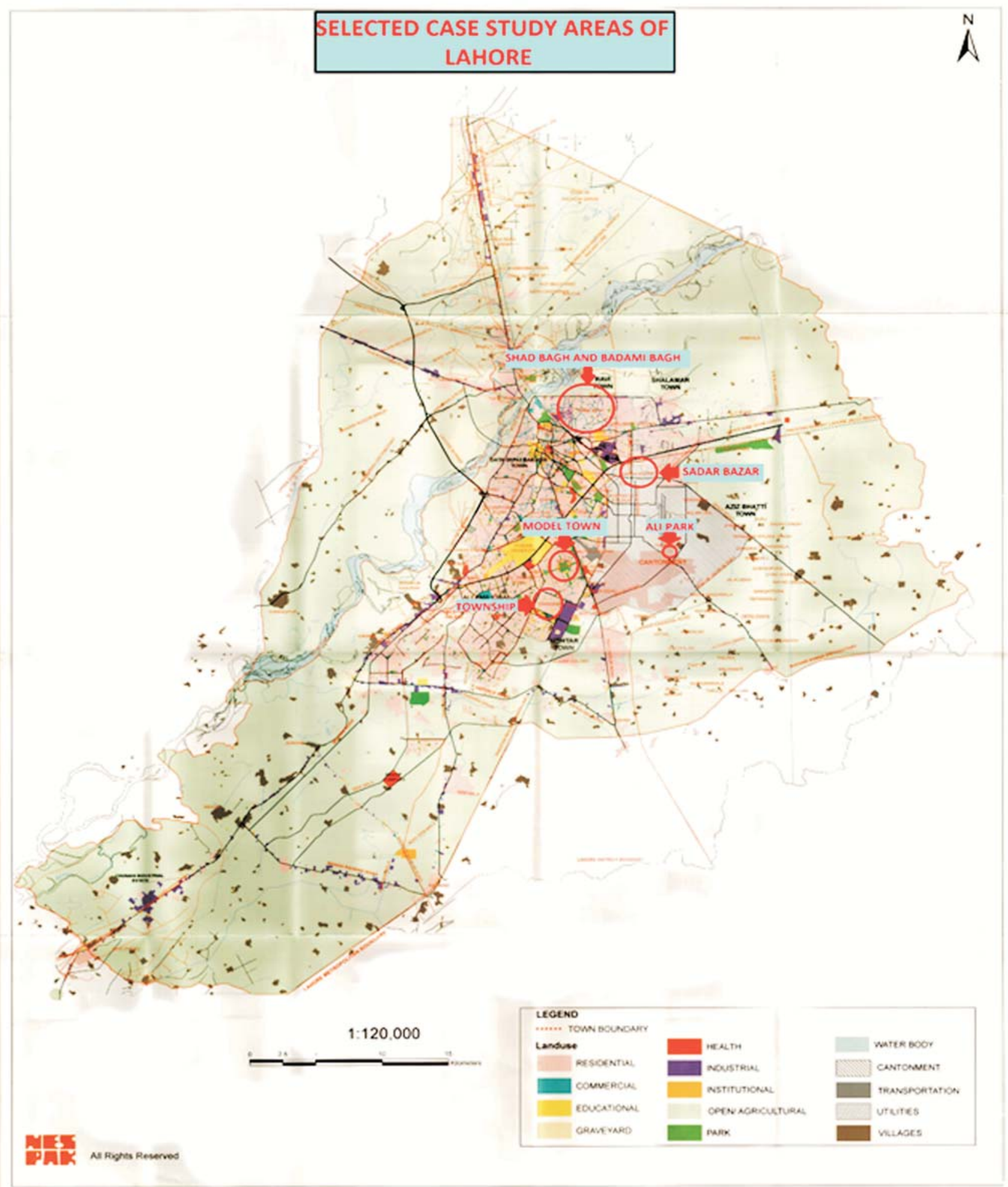

Figure-2: Map of Surveyed Areas.

Source: Integrated Master Plan Lahore 2021 
according to which the sample size of thirty is appropriate for any survey. Four case study areas from Lahore have been selected and a sample of thirty from each selected area was collected, making a total of one hundred and twenty questionnaires. The collected data was assimilated and assessed in relation to different factors, leading towards concrete conclusions.

Furthermore, interviews were conducted of officials who are responsible for implementation of building control in their areas.

\section{LITERATURE REVIEW}

Building byelaws have different concept in different countries. In general there are the mandatory spaces, floor area ration (FAR), building heights and parking spaces. Some countries have their own opinions regarding the term building byelaws. They define it as anything which is approved by the development authorities, includeing façade of building, texture, exterior design, window height and everything covering the size and aesthetics of building.

There are mostly two types of building codes adopted in different countries national building codes and local building codes. The former one includes development of codes by the national government and enforced by central government, while the latter one includes development of building codes by the local area authority, keeping in view certain specific conditions and requirements of concerned areas, for instance requirements of a hilly area may be quite different from those in plainar areas.

TK and Dist (2012) have identified three basic reasons of byelaws violation; first is due to high cost of land, second is due to administrative negligence and third is due to unawareness. Lack of monitoring machinery, shortage of technical manpower at the municipal level are the major concern of the municipal councils to control and avoid such violations from its occurrence. Some have felt that the local political influence is also a hurdle in controlling such violations. The researchers have recognized the three-tier system, due to which successful implementation can be achieved, along with real time information and control system and violation reducing mechanism.

Lent (2015) identifies that for building byelaws in Canada two basic things are important; first is the building byelaw itself and the second is the house rules. She has explained difference between these two, house rules are those rule related to city aesthetics, color, material and size, while building byelaws are related to the section of the city which is under the control of a regulating authority.
Developed countries, like UK and Canada, which are efficiently implementing their building codes, are far advance in their regulations. Their advancement is both in types of building codes as well as their implementation strategies. In most of the developed countries, building material, air ventilation, ramp designs for disabled, building façade, window orientation, stair design and much more is considered as part of building byelaws. While on the other hand in Pakistan, building regulations are restricted to only building height, mandatory open spaces, floor area ratio and ground coverage.

It is also a common practice in developed countries to have building regulations available online. In addition to this, many countries offer a facility of online building plan approval. By this facility people can easily submit their plans online for approvals. Many countries have launched different kinds of website on which only by entering locations and dimensions one would get all the information regarding building byelaws. Websites, like e-planning scrutiny, by Madurai Corporation, is an example of this online plan approval system (Anon, 2015a).

\section{Public Private Partnership}

It is a common practice to resolve regulation implementation problems through the participation of public and private bodies. By seeing the benefits of this practice many international governments have become involved in the private, sector to implement building byelaws effectively and efficiently. As the private sector is more responsible, so it governs the implementing authority and ensures successful implementation of building codes. In the case study areas of Lahore, one of the main problems for failure in implementation was the lack of good governance. Authorities had overlapping functions and had no proper chain of command, which meant that they could not have any check, balance and accountability. In the case of Model Town Cooperative Society, due to the involvement of community in the management through an election system, implementation of building byelaws was successful. Thus, adaptation of international practice of involving private sector along the government sector, in instigating building regulations, can improve building regulation practices (Heijden, 2014).

\section{FINDINGS}

The results obtained from the researh were majorly an outcome of the following:

- Comparison of authority's jurisdiction area through questionnaires 
- An analysis of factors contributing to the effective implementation of building byelaws

- Social factors

- Economic factors

- Organizational factors

- Analysis of the view point of officials through interview performa

The following variables were used to collect the data via questionaires:

- Household

- Approved house plan

- Attainment of completition certificate

- Owner education

- Corruption level

- Satisfaction of communication

- Owner occupation

- Official behavior

- Reason for no approval

- Amendment plan approval

- Monthly income

- Year of construction

- Plan approval time

- Inspection by the inspector

- Plan approval fee per sq feet

\section{House Hold Size of respondents}

Areas in which on average more than one family per house is living, building byelaws are violated because of accommodation requirement. By this analysis it was found that in TMA most of the houses have two or more families, living in them, as compared to other authorities in Lahore. The case is vice versa for MCS and LCB. In TMA controlled areas the household size is higher as compared to other areas and is one of the reasons for not complying to building regulations (Figure 3).

\section{Level of education of respondents}

The results show that in MCS and LCB mostly respondents were educated up to and above graduation level, but on the other hand respondents of TMA and LDA were not highly educated and had basic education. The hypothesis that education can affect the implementation of building byelaws was not supported according to the findings of this research. Though education brings awareness but in this case the strict implementation of byelaws was more effective rather than education level of residents (Figures 4 and 5).

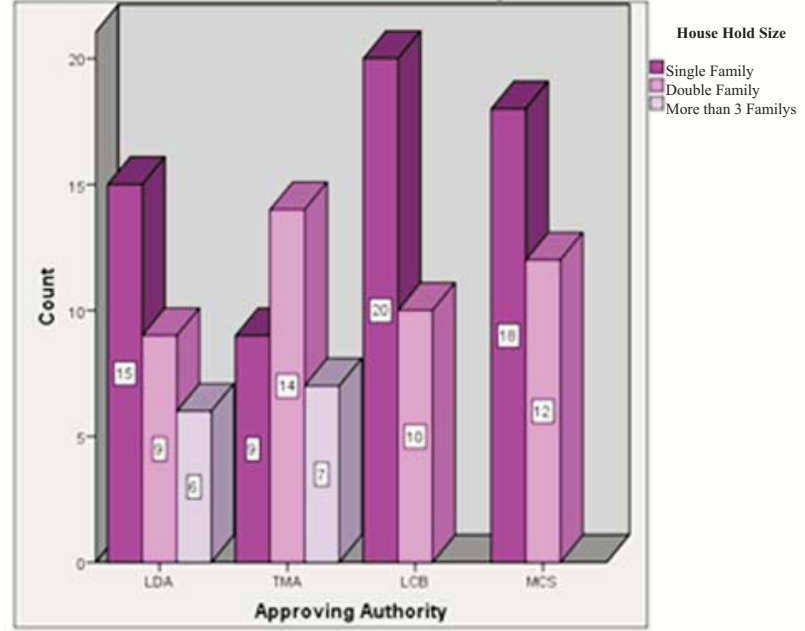

Figure-3: Household size in differnt jurisdictions.

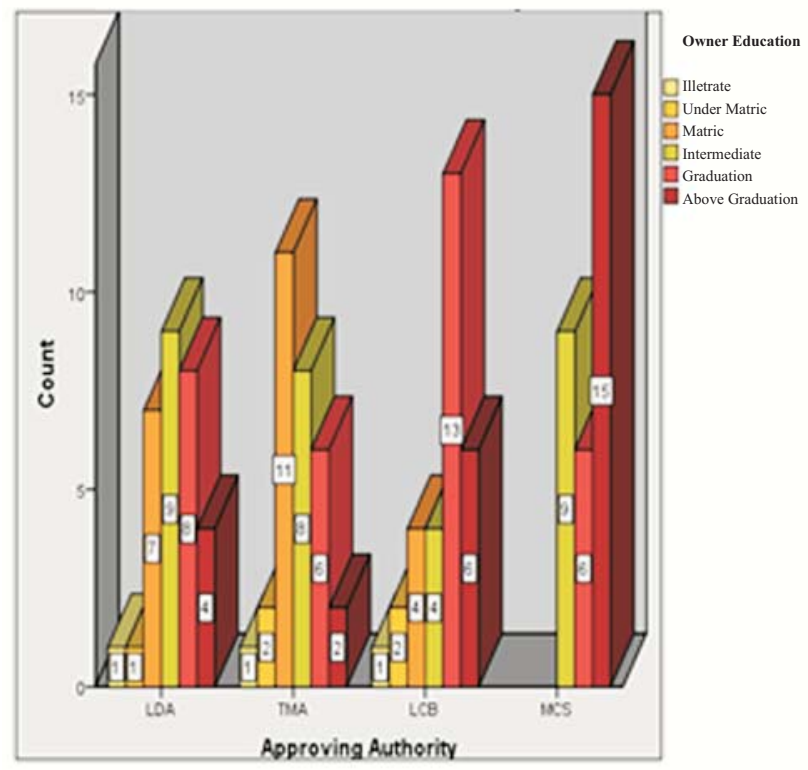

Figure-4: Owner education vs. development authorities.

\section{Corruption within regulating bodies}

After the analysis of this factor it was revealed that MCS can be taken as an ideal case because 100\% respondents were of the view that there is no corruption in this authority, and they trust their authority completely. This was one of the main reasons for successful implementation of the building regulations. While on the other hand in TMA most of the respondents did not have any interaction with the authority, so they didn't have any idea about the corruption 
level of TMA. According to the respondents of LDA, corruption level was very high, and same was the case with LCB. Confidence level in the authority was thus one factor that lead to better implementation of building byelaws or approval of plans before start of construction by the relevant authority.

\section{Approved house plan vs. development authority}

$100 \%$ of house plans were approved by the MCS authority, while LCB also had significant control in its area and more than $85 \%$ plans were approved from the authority, while LDA had a mixed trend of approved and not-approved status due to weak enforcement. In contrast TMA had a unique behavior showing that more than $70 \%$ house plans were not approved from the authority. This was due to old construction of houses and also because the control of authority was weak in the areas under its jurisdictions (Figure 6).

\section{Inspection by building inspector during construction phase}

The research also revealed that inspection visit was part of implementation of building byelaws from authority officals and in the case of MCS and LCB visits were made at the time of damp proof course (DPC) execution. But in the case of LDA and TMA, official visited only $50 \%$ of the sites under construction and it was also one of the reasons why there was violation even after approval of building plans.

\section{Completion Certificate vs. Development Authority}

Results also revealed that $100 \%$ of the people had completion certificate in the case of MCS, after the completion of construction of housing unit. The basic reason behind this was that the authority did not give connections of basic utilities (electricity, gas) to the people unless until they got a completion certificate from the authority. In LCB almost $50 \%$ people had completion certificates, but in LDA only limited people got completion certificates from the authority.

\section{Plan Approval Fee}

The data related to the plan approval fees of residential building paid by house owners represents that MCS takes $36 \mathrm{Rs} / \mathrm{sq} . \mathrm{ft}$ for the approval of a plan, LCB charges $6 \mathrm{Rs} /$ sq.ft, similarly LDA, TMA charge 5 Rs/ sq.ft and 2 Rs/ sq.ft respectively. This trend represents that MCS charges highest and has efficient management system. It also points towards the fact that high plan approval fees also means low corruption levels.

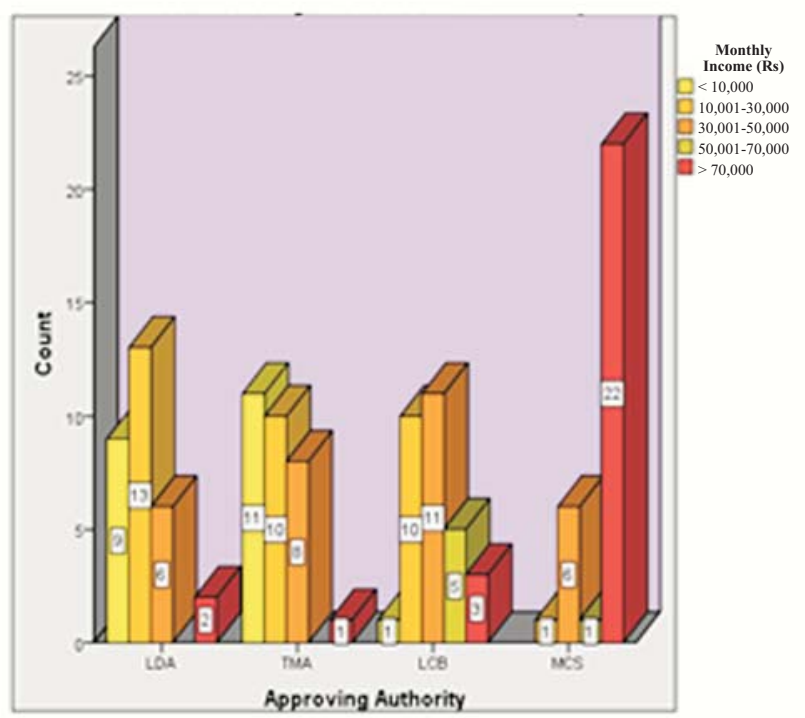

Figure-5: Owner monthly income Vs. development authority.

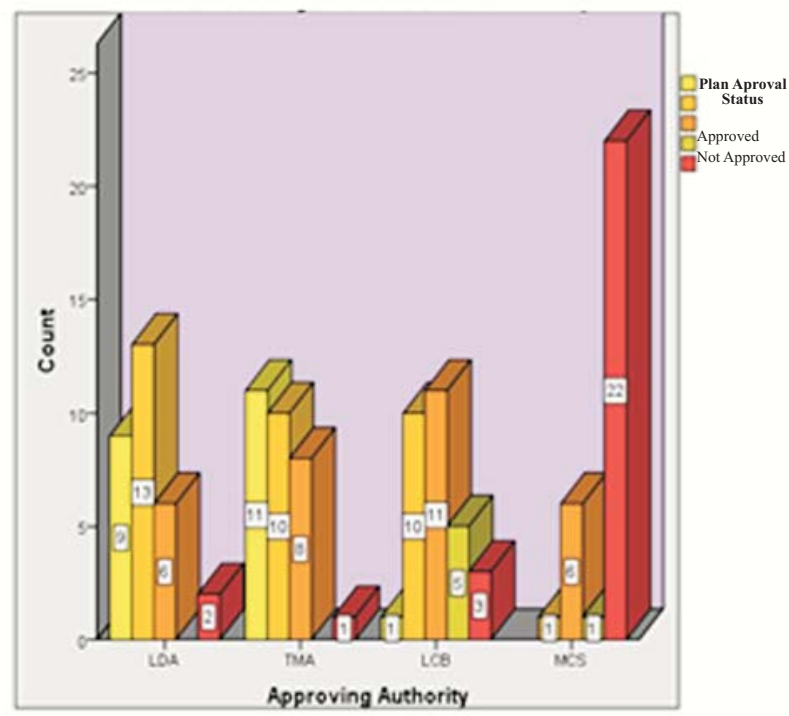

Figure-6: House plan approval Vs. development authorities.

\section{Institutional Analysis}

Qualitative interviews were conducted with officials of all authorities reviewed here. They were asked various types of questions to give a clear picture about their organisations, which further helped identify the factors of success and impediments in implementation of building codes. Questions relating to their work force, logistics, areas which are most violated and the average socio-economic status of people living in these vicinities and set of rules adopted in their 
authorities for building control, were asked. Furthermore, the social factors contributing to implementation as well as the political influence, if any, behind ineffective or effective implementation of building regulations, were inquired. In addition to this, they were also asked whether they have made any efforts to integrate their existing system with international practices as well as what are the good and deficient points of their system.

\section{Area Types}

In Model Town there was no division of violated and nonviolated areas, according to the interviews conducted, as houses were built according to the byelaws. In Lahore Cantonment the main Cantt area had no violation in which mostly army personal are living and are of high income level and are well educated. Secondly the Bazar Area of mixed development in which some of the houses were built according to the byelaws but others were not. Most of the houses which were not built according to byelaws were very old. Their income level was still high, but education level was average. The most violated areas under LCB were extended areas, which mostly had a rural characterc and was recent addition to LCB. Their income and education levels were below average. Amongst the areas under LDA, private schemes were non-violated, regular schemes were mixed land use areas and were highly violated. In our case study of TMA none of the areas can be said to be nonviolated. Shadbagh can be taken as an example of mixed land use where there was an equal ratio of approved and non-approved building plans. Areas of Badami Bagh and Shadara within TMA were highly violated areas.

\section{Span of Control}

As the Cooperative Model Town Society had a small area under its control as compared to other authorities responsible for building control, they did not receive plan approval applications on a daily basis. In LCB on an average three to four applications, in LDA five to six applications and in TMA one to two applications were received daily for approval.

\section{Work Force}

MCS has a work force of ten people working for them out of which two are building inspectors two are draftsmen four are assistant road inspectors, two are assistants. These people are using their private logistics for site visits. During the construction of any house they visit the site three times. In LCB six building inspectors are working along with the required staff members for building control and use the transport of the Cantonment Board to make site visits. During construction of any house they are required to visit the site two times. In LDA, one town planner is responsible for big areas and he does not have logistics for the visit. During the construction of any house he is required to visit the site five times. In TMA Ravi Town there are five building inspectors and twenty to twenty five other staff members responsible for inspection visits and they use private vehicles. During construction of any house they are required to visit the site two times. When it comes to making the site visits only MCS official make regular site visits.

\section{Political Influence}

In Model Town there is no influence of politicians and the staff is fulfilling their duties efficiently. In LCB, in some areas there is little political influence but rest of the areas are free from it. Areas under LDA and TMA are facing great political influence, which may be the reason behind their ineffective system as compared to MCS and LCB.

\section{Social Influence}

Civic sense, education, income level, community empowerment, sense of responsibility, lack of awareness among people, lack of technical understanding, copying neighbors for violations, ignorance, personal interests, no respect of authorities and pressure group's involvement are all the social factors that are impediments in the implementation of the building byelaws in the various localities.

\section{Public Participation}

In Model Town decision making regarding planning issues is done by involving the general public which is why people generally trust their society and cooperate with them. In addition quick inspection and no corruption are other good practices of MCS. LCB has a building control cell, which ensures good scrutiny, proper check and balance and minimizes political influence. But in addition to this in their building byelaws there are some conflicts related to byelaws of five marla houses and bungalows. According to the representatives of LDA, flexibility in their system is a good practice and their deficiencies include lack of public participation and ineffective system of implementation. Sufficient staff members, skilled personal, mechanism for building byelaws implementation are the good practices of TMA and their deficiencies include lack of proper check and balance, under utilised staff, non-technical staff, unawareness of importance of building byelaws and rigid systems of implementation of building byelaws. 
Table-2: Comparison of Selected Building Control Authorities.

\begin{tabular}{|c|c|c|c|c|c|c|c|c|c|c|c|c|}
\hline \multicolumn{13}{|c|}{ Analysis of Results } \\
\hline Authorities / Catagories & \multicolumn{3}{|c|}{ The Cooperative Modal Town Society } & \multicolumn{3}{|c|}{ Lahore Cantt } & \multicolumn{3}{|c|}{$\begin{array}{l}\text { Lahore Development } \\
\text { Authority }\end{array}$} & \multicolumn{3}{|c|}{ TMA Ravi Town } \\
\hline Approved : Not Approvф & \multicolumn{3}{|c|}{$1: 0$} & \multicolumn{3}{|c|}{$4: 1$} & \multicolumn{3}{|l|}{$1: 1$} & \multicolumn{3}{|c|}{$1: 5$} \\
\hline Characteristics & $\begin{array}{l}\text { Non Violated } \\
\text { Areas }\end{array}$ & $\begin{array}{l}\text { Mix } \\
\text { Area }\end{array}$ & $\begin{array}{l}\text { Violated } \\
\text { Areas }\end{array}$ & $\begin{array}{l}\text { Non Voilated } \\
\text { Areas }\end{array}$ & $\begin{array}{l}\text { Mix } \\
\text { Areas }\end{array}$ & $\begin{array}{l}\text { Voilated } \\
\text { Areas }\end{array}$ & $\begin{array}{c}\text { Non Voilated } \\
\text { Areas }\end{array}$ & $\begin{array}{l}\text { Mix } \\
\text { Areas }\end{array}$ & $\begin{array}{c}\text { Voilated } \\
\text { Area }\end{array}$ & $\begin{array}{c}\text { Non Voilated } \\
\text { Areas }\end{array}$ & $\begin{array}{l}\text { Mix } \\
\text { Area }\end{array}$ & $\begin{array}{c}\text { Voilated } \\
\text { Area }\end{array}$ \\
\hline Area Division & Whole area & & & Main Cantt & $\begin{array}{l}\text { Bazaar } \\
\text { Area }\end{array}$ & $\begin{array}{l}\text { Extended } \\
\text { Area } \\
\end{array}$ & \begin{tabular}{|l} 
Private \\
Schemes
\end{tabular} & $\begin{array}{l}\text { Regular } \\
\text { Schemes }\end{array}$ & $\begin{array}{l}\text { Controlled } \\
\text { Area } \\
\end{array}$ & None & Shadbagh & $\begin{array}{l}\text { BadamiBagh, } \\
\text { Shahdra }\end{array}$ \\
\hline Income Level & High & & & High & Middle & $\begin{array}{l}\text { Middle/ } \\
\text { Lower }\end{array}$ & High & Middle & Less & & High & $\begin{array}{l}\text { Middle/ } \\
\text { Lower }\end{array}$ \\
\hline Education Level & High & & & High & High & Medium & High & High/ & Low & & Medium & Medium/ \\
\hline Occupation & $\begin{array}{l}\text { Traders, } \\
\text { Entrepreneur, } \\
\text { Bureaucrats }\end{array}$ & & & $\begin{array}{l}\text { Army Officers, } \\
\text { Entrepreneurs }\end{array}$ & $\begin{array}{l}\text { Army } \\
\text { Officer, } \\
\text { Govt } \\
\text { Employee }\end{array}$ & $\begin{array}{l}\text { Army } \\
\text { Officer, } \\
\text { Govt// } \\
\text { Private } \\
\text { Employee }\end{array}$ & $\begin{array}{l}\text { Entrepreneur, } \\
\text { Govt. Employee }\end{array}$ & $\begin{array}{l}\text { Govt. } \\
\text { Employee }\end{array}$ & \begin{tabular}{|l|} 
Private \\
Employee \\
Workers
\end{tabular} & & $\begin{array}{l}\text { Entrepre- } \\
\text { neur }\end{array}$ & $\begin{array}{l}\text { Govt. Put } \\
\text { Employee, } \\
\text { Entrepreneur }\end{array}$ \\
\hline $\begin{array}{l}\text { Average Daily Building } \\
\text { Approval Application }\end{array}$ & \multicolumn{3}{|c|}{ No one on daily basis } & \multicolumn{3}{|c|}{$3-4$} & \multicolumn{3}{|c|}{$5-6$} & \multicolumn{3}{|c|}{$1-2$} \\
\hline Total Work Force & \multicolumn{3}{|l|}{10} & \multicolumn{3}{|c|}{30} & \multicolumn{3}{|c|}{1} & \multicolumn{3}{|c|}{30} \\
\hline Division of Work Force & \multicolumn{3}{|c|}{$\begin{array}{l}\text { Building Inspector: 2, } 2 \text { Dross man site, } 4 \text { Assistant } \\
\text { road inspection, } 2 \text { Assistant }\end{array}$} & \multicolumn{3}{|c|}{6 Inspector, Demolition } & \multicolumn{3}{|l|}{1 Site Inspector } & \multicolumn{3}{|c|}{5 for Site Inspection } \\
\hline Total Visits for inspection & \multicolumn{3}{|l|}{3} & \multicolumn{3}{|c|}{2} & \multicolumn{3}{|c|}{5} & \multicolumn{3}{|c|}{2} \\
\hline Logistics & \multicolumn{3}{|c|}{ Private Motor Bikes } & \multicolumn{3}{|l|}{3 Govt. Vehicles } & \multicolumn{3}{|l|}{ Private Vehicle } & \multicolumn{3}{|c|}{ Personal vehicles } \\
\hline Law/Act Applicable & \multicolumn{3}{|c|}{$\begin{array}{l}\text { The Cooperative Modal Town Housing Society } \\
\text { Act } 1962\end{array}$} & \multicolumn{3}{|c|}{ Building Byelaws 2008} & \multicolumn{3}{|c|}{ LDA Land use Rule 2014} & \multicolumn{3}{|c|}{$\begin{array}{l}\text { PLGO 2001, Land use Classification and } \\
\text { Reclassification Rules } 2009\end{array}$} \\
\hline $\begin{array}{l}\text { Political Influence in } \\
\text { implementation }\end{array}$ & No & & & $\begin{array}{l}\text { No influence bef } \\
\text { will Influence aft }\end{array}$ & $\begin{array}{l}\text { Elections, M } \\
\text { Elections }\end{array}$ & & $\begin{array}{l}\text { MNAs, MPAs, S } \\
\text { influence in impl }\end{array}$ & $\begin{array}{l}\text { al Media too } \\
\text { entation }\end{array}$ & much & $\begin{array}{l}\text { Too much polit } \\
\text { of building bye } \\
\text { industries }\end{array}$ & $\begin{array}{l}\text { Influence in } \mathrm{i} \\
\text { specially in } \mathrm{c}\end{array}$ & $\begin{array}{l}\text { implementation } \\
\text { commercial and }\end{array}$ \\
\hline Effectiveness of Social Factor & General Meetir & Public & & $\begin{array}{l}\text { Civic Sense, Edu } \\
\text { of Persons }\end{array}$ & ion and Incor & me Level & $\begin{array}{l}\text { Community Emp } \\
\text { responsibility, Ed }\end{array}$ & $\begin{array}{l}\text { rerment, Sens } \\
\text { ation }\end{array}$ & se of & $\begin{array}{l}\text { People who tak } \\
\text { follow building }\end{array}$ & $\begin{array}{l}\text { ik loan for co } \\
\text { aws }\end{array}$ & onstruction they \\
\hline Ineffectiveness of Social Factor & I None & & & Pressure group In & lvement & & $\begin{array}{l}\text { Illiteracy, Ignorar } \\
\text { No respect of Au }\end{array}$ & Self-interes & & $\begin{array}{l}\text { Lack of Awarer } \\
\text { technical under } \\
\text { own neighbor f }\end{array}$ & $\begin{array}{l}\text { mong peopl } \\
\text { ling among } \mathrm{p} \\
\text { olation }\end{array}$ & $\begin{array}{l}\text { le, Lack of } \\
\text { people, Copying }\end{array}$ \\
\hline Positive Points of System & $\begin{array}{l}\text { Small Area, Qu } \\
\text { Decision throu }\end{array}$ & $\begin{array}{l}\text { Inspectiol } \\
\text { eeting }\end{array}$ & No Corruption, & $\begin{array}{l}\text { Building Control } \\
\text { Proper Check anc } \\
\text { Influence }\end{array}$ & $\begin{array}{l}\text { 11, Good Scru } \\
\text { alance, No P }\end{array}$ & $\begin{array}{l}\text { utiny, } \\
\text { Political } \\
\end{array}$ & Flexibility & & & $\begin{array}{l}\text { Sufficient Staff } \\
\text { mechanism for }\end{array}$ & $\begin{array}{l}\text { aber, Skilled } \\
\text { ing byelaws }\end{array}$ & $\begin{array}{l}\text { Person, Proper } \\
\text { implementation }\end{array}$ \\
\hline Negative points of System & None & & & $\begin{array}{l}\text { Conflict in Byela } \\
5 \text { Marla House, } \\
\text { Less Salary Pack }\end{array}$ & $\begin{array}{l}\text { for Bungalov } \\
\text { uption, Time }\end{array}$ & $\begin{array}{l}\text { ws and } \\
\text { e Delay, }\end{array}$ & $\begin{array}{l}\text { No effective syst } \\
\text { Lack of people pa }\end{array}$ & $\begin{array}{l}\text { of implemen } \\
\text { cipation }\end{array}$ & ntation, & $\begin{array}{l}\text { Not fully utilize } \\
\text { Balance, Non-T } \\
\text { importance of b } \\
\text { implementation }\end{array}$ & $\begin{array}{l}\text { ff, No proper } \\
\text { ical Staff; un } \\
\text { ng byelaws, I }\end{array}$ & $\begin{array}{l}r \text { Check and } \\
\text { nawareness of } \\
\text { Rigid System of }\end{array}$ \\
\hline $\begin{array}{l}\text { Suggestion to improve the } \\
\text { efficiency of system }\end{array}$ & $\begin{array}{l}\text { Division of Lar } \\
\text { help in efficien }\end{array}$ & rea for ot & authorities will & $\begin{array}{l}\text { Remove the conf } \\
\text { Presence of Acco }\end{array}$ & $\begin{array}{l}\mathrm{s} \text { in building } \\
\text { ability }\end{array}$ & byelaws, & $\begin{array}{l}\text { Capacity Buildin } \\
\text { Provision of effic } \\
\text { present and provi } \\
\text { people, Less invo } \\
\text { implementation }\end{array}$ & $\begin{array}{l}\text { f Institutions, } \\
\text { t staff should } \\
\text { the logistics } \\
\text { ement of polit }\end{array}$ & $\begin{array}{l}\text { s, } \\
\text { td } \\
\text { to the } \\
\text { itics in }\end{array}$ & $\begin{array}{l}\text { Corruption shot } \\
\text { to lessen the po }\end{array}$ & $\begin{array}{l}\text { emove from } t \\
1 \text { impact on } i\end{array}$ & $\begin{array}{l}\text { the system, try } \\
\text { implementation }\end{array}$ \\
\hline
\end{tabular}

\section{Overview}

Table 2 compares the four authorities reviewed here, in terms of implementation of building byelaws, highlighting the social, economic and organizational factors in the implementation phase and emphasizing the difference in the setup of the authorities. Out of all, it has been assessed that MCS turns out to be the best functioning authority in terms of building controls implementation.

\section{Conclusion and Recommendations:}

The importance of building byelaws cannot be negated in the field of town planning due to its grave importance. In this research the reasons and factors which help the authorities to successfully implement building regulation in their control areas have been identified. General public as well as the organizational behavior of authorities is involved in effective implementation. From the analysis it is concluded that plan approval of house is not dependent on household income and occupation of residents but, community participation and good governance impact upon implementation of byelaws. Thus, it is concluded that amongst the for authorities reviewed here, Model Town is working most efficiently because they have a small control area with less population density and they ensure public participation in every new decision regarding building byelaws. Lahore Cantonment Board, which is responsible to implement byelaws in Cantonment area, have building byelaws which are not up to the standard of Model Town, but their strict scrutiny ensures efficient implementation of building byelaws. LDA has a well-established administrative structure, but the factor of corruption hinders its efficient implementation of byelaws 
and regulations. In addition to this they have large control areas and high population density, similar to areas under TMA. Existence of old houses also becomes a hurdle in the implementation of building byelaws. Lastly it can be concluded that the success of building byelaws and regulations is largely dependent on public participation and awareness.

\section{RECOMMENDATIONS TO IMPROVE THE IMPLEMENTATION OF BUILDING BYELAWS}

\section{Public participation}

Public participation should be ensured while making decisions by the authorities so that people own them. This also establishes a sense of ownership amongst the public. In MCS they invite general public and their views are heaved before making any type of changes in the existing byelaws. This approach should be adopted by other authorities too.

\section{Flexibility}

Flexibility, in terms of building design, should be given to the general public by the authorities while building their houses. Different options should be given to the public so they can opt for the one which best suits them. For instanec in Lahore Cantonment Board the final authority is in the hands of Board's members and they can approve the plan after analyzing the current situation regardless of approved byelaws. This helps in considering the users needs to implement byelaws efficiently. The best practice is to set minimum safety standards and leave choices for dwellers with elaborated standing operational procedures outlined.

\section{Good Governance}

In order to reduce corruption level in authorities like LDA and TMA proper check and balance should be introduced by the higher authorities. Accountability of the staff members should be ensured and a clear chain of command and good governance should be provided.

\section{Updated Building Byelaws}

Building byelaws should be updated after appropriate intervals according to present needs. Online resources should be developed that can calculate the fee, provide easy access to building byelaws and the process of applying for approvals.

\section{REFERENCES}

Anon, 2015, "Stratified Random Sampling” viewed 20-04-2015, form http://www.stat.ualberta.ca/ prasad/361/STRATIFIED Random Sampling.pdf.

Anon, 2015a, “Online Building Plan Approval System”, viewed 19-04-2015, from http://203.101.40.168/newmducorp/building/page2.aspx.

Heijden, J. V. D., 2014, “Governance for Urban Sustainability and Resilience: Responding to Climate Change and the Relevance of the Built Environment", viewed 18-04-2015, from https://books.google.com/books?id=NoK1BAAAQBAJandpgis=1.

Lent, L., 2015, “The Cooperator New york, News Issue on Property” viewed 28-09-2016, from www.newyorktimes.com.

Tk, V. and Dist, V., 2012, "Violation of building bye-laws and development control rules: A Case Study", www.iosrjournal s.org/iosr-jmce/papers, Vol. 2(4): 48-59. 